\title{
PENYELESAIAN KONFLIK PERKAWINAN DITINJAU DARI USIA PERKAWINAN
}

\author{
Sitti Murdiana \\ Universitas Negeri Makassar \\ Email Korespondensi : Sittimurdiana@yahoo.co.id
}

\begin{abstract}
Abstrak
Tingginya jumlah pasangan yang memutuskan untuk bercerai, yang disebabkan penyelesaian konflik perkawinan yang tidak terselesaikan dengan baik. berdasarkan hal tersebut penelitian ini bertujuan untuk mengetahui bagaimana gambaran penyelesaian konflik perkawinan pada pasangan menikah ditinjau dari usia perkawinan. Subjek penelitian ini terdiri dari 833 pasangan menikah yang terdiri dari 378 laki-laki dan 455 perempuan yang tersebar di Kota Makassar dengan kriteria telah menikah. Alat ukur penelitian ini menggunakan skala penyelesaian konflik perkawinan konstruktif dan skala penyelesaian konflik destruktif data yang diperoleh diolah menggunakan independent Sample T-test dengan bantuan program SPSS for windows 22. Hasil penelitian menunjukkan bahwa penyelesaian konflik perkawinan dapat dibedakan berdasarkan usia perkawinan. Hasil penelitian ini menunjukkan bahwa terdapat perbedaan penyelesaian konflik perkawinan sesuai usia perkawinan. Kesimpulan penelitian ini adalah penyelesaian konflik perkawinan berdasarkan kategori dapat ditinjau berdasarkan usia perkawinan.
\end{abstract}

\section{PENDAHULUAN}

Konflik didefinisikan dalam kamus psikologi oleh Reber \& Reber (2010) merupakan situasi apa pun yang didalamnya terdapat kejadian atau peristiwa, motif, tujuan, perilaku, dorongan yang sama-sama bertentangan. Kondisi ini terjadi dalam lingkup kelompok sosial, organisasi, internasional, maupun dalam hubungan interpersonal. Konflik pada pasangan menikah dikategorikan ke dalam konflik interpersonal. Konflik interpersonal juga didefinisikan sebagai interaksi antara dua orang atau lebih yang mengekspresikan minat yang berbeda, pandanganpandangan, atau opini yang bertentangan (Bell \& Blakeney dalam Kline, Pleasant, Whitton \& Markman, 2006).

Konflik terjadi ketika motif seseorang, tujuan, kepercayaan, opini, atau perilaku terganggu, atau terhadalangi oleh orang lain (Miller \& Pearlman, 2009). Konflik terjadi karena adanya ketidak sesuaian antar kedua belah pihak, yang ditampilkan dalam bentuk mood, atau bentuk keyakinan dan kepribadian. Menurut Dal Cin dalam Miller \& Pearlman (2009), dua orang selalu berbeda dalam bertindak, akan tetapi makna konflik lebih sering dihubungkan dengan keaktivan dalam mengganggu tujuan orang lain. Konflik terjadi ketika keinginan atau tindakan seseorang mengganggu atau menghalangi tujuan atau keinginan orang lain. Dal Cin dalam Miller \& Pearlman (2009) juga menambahkan bahwa ketika pasangan memiliki pandangan yang berbeda satu sama lain, potensi terjadinya konflik semakin nyata, tetapi ketika mereka secara pribadi memutuskan untuk berbeda tanpa membuat atau mengungkapkan ketidaksetujuan maka kemungkinan konflik tidak akan terjadi.

Sejumlah ahli sepakat bahwa konflik dalam perkawinan merupakan hal yang tidak dapat dihindari. Konflik seringkali dipicu oleh adanya perbedaanperbedaan antara individu dengan pasangannya. Menurut Miller dan Perlman (2009) terdapat dua alasan mengapa konflik sangat sukar dihindari dalam sebuah perkawinan, alasan pertama yaitu karena pada setiap individu memiliki perbedaan mengenai suasana hati dan minat. Pasangan suami-istri pun seringkali mengalami perbedaan tujuan dan tingkahlaku yang sulit dihindari. Konflik juga sukar dihindari karena adanya tekanan yang terjadi dalam hubungan pasangan tersebut, sehingga menyebabkan munculnya ketegangan sewaktu-waktu.

Menurut Gottman (1994) dalam sebuah perkawinan, individu menghadapi sejumlah isu-isu perkawinan yang dapat menimbulkan konflik. Pasangan menikah akan dihadapkan oleh berbagai permasalahan yang sederhana dan kompleks yang dapat memicu konflik. Meski konflik dan ketegangan tidak selalu mengindikasikan ketidakstabilan dalam perkawinan, banyak pasangan hanya menghadapinya sebagai sebuah problematik (James \& Wilson, 2002). Gottman (1994) berpendapat bahwa sebagian pasangan menikah menilai konflik sebagai gangguan kecil dalam perkawinan, tetapi bagi pasangan yang lain bisa menjadi lebih kompleks dan lebih sering terjadi. Bila seseorang sering merasa terganggu akibat konflik yang dialaminya, atau merasa memiliki jarak dengan pasangannya, maka konflik dapat menjadi suatu peringatan atau ancaman bagi hubungan individu dengan pasangannya.

Konflik yang terjadi dalam sebuah perkawinan tidak dapat dibiarkan terus terjadi, harus ada upaya untuk mengatasi konflik yang terjadi agar dampak negatif yang ditimbulkan akibat terjadinya konflik dapat dihindari. Konflik yang tidak terselesaikan dengan baik akan memberi dampak negatif terhadap kehidupan perkawinan dan juga berdampak jangka panjang bagi anggota keluarga yang lain. Oleh karena itu peneliti memandang bahwa pola penyelesaian konflik perkawinan perlu dikaji lebih jauh. Penelitian ini akan membahas pola-pola penyelesaian konflik perkawinan dan faktor-faktor yang mempengaruhi terbentuknya pola penyelesaian konflik perkawinan pada individu. Hocker \& Wilmott dalam Lim (2000) mendefinisikan penyelesaian konflik perkawinan sebagai kumpulan respon atau sejumlah tingkah laku yang digunakan oleh individu ketika menghadapi konflik dengan pasangannya. 
Deutsch dalam Deutsch, Coleman, \& Marcus, (2006) menjelaskan bahwa individu melakukan penyelesaian konflik dengan dua proses yaitu; proses yang bersifat konstruktif dan proses yang bersifat destruktif. Proses yang bersifat konstruktif merupakan proses penyelesaian konflik yang dilakukan secara kooperatif, sedangkan proses penyelesaian konflik yang bersifat destruktif melibatkan proses kompetitif untuk mencapai kemenangan salah satu pihak. Gottman (1994) mengungkapkan penyelesaian konflik perkawinan mengarahkan individu untuk mencapai dua hal yaitu: 1) Memecahkan masalah yang dihadapi, dan sepakat untuk tetap bersama menjalani perkawinan mereka; 2) Bersedia mengidentifikasi dan mendefinikan sejumlah perbedaan yang terjadi diantara mereka, dan bersedia menggunakan tradisi sebagai strategi coping dalam menghadapi konflik perkawinan.

Penelitian ini membahas penyelesaian konflik perkawinan yang bersifat konstruktif dan destruktif, berdasarkan temuan peneliti setelah dilakukan pengelompokan dan analisis terhadap pola perilaku perempuan mengenai cara penyelesaian konflik. Hal ini didukung pula oleh pendapat Deutsch dalam Deutsch, Coleman, \& Marcus, (2006) bahwa penyelesaian konflik memiliki dua proses yaitu; proses yang bersifat konstruktif dan proses yang bersifat destruktif. Proses yang bersifat konstruktif merupakan proses penyelesaian konflik yang dilakukan secara kooperatif, sedangkan proses penyelesaian konflik yang bersifat destruktif melibatkan proses kompetitif.

Tipe penyelesaian konflik yang konstruktif menampilkan perilaku-perilaku solvable dan resolved (terpecahkan) terhadap permasalahan yang dihadapi (Gottman, 1994). Sedangkan tipe destruktif lebih mengarah pada perilaku-perilaku yang merusak hubungan interpersonal dengan pasangan. Hal ini diungkapkan pula oleh Gottman dalam Miller \& Perlman (2009) dan Bermunez (2002), bahwa terdapat dua pola penyelesaian konflik yang bersifat konstruktif dan penyelesaian konflik yang bersifat destruktif.

Kategori tersebut didasarkan pada indikator yang mengungkapkan bahwa pola penyelesaian konflik yang konstruktif menampilkan sikap-sikap positif yang dapat diterima oleh kedua belah pihak dan memudahkan tercapainya kesepakatan antara individu dengan pasangannya, sedangkan pola penyelesaian konflik yang destruktif menampilkan sikap-sikap negatif yang memungkinkan munculnya penolakan, bahkan perselisihan berkepanjangan yang menyulitkan tercapainya kesepakatan antara individu dengan pasangannya.

Pola penyelesaian konflik yang kontruktif diwakili oleh indikator-indikator yang mengarah pada tindakan-tindakan yang dapat dipahami dan diterima oleh pasangannya dalam menyelesaikan konflik perkawinan. Penelitian ini mengacu pada pola penyelesaian konflik yang dihasilkan pada studi awal, serta prinsip-prinsip penyelesaian konflik perkawinan yang di kemukakan oleh Gottman (1994) yang diaplikasikan untuk mengukur penyelesaian konflik perkawinan yang bersifat konstruktif dan prinsipprinsip penyelesaian konflik yang bersifat destruktif.
Berdasarkan kedua kajian tersebut, kemudian peneliti menetapkan indikator pola penyelesaian konflik perkawinan yang konstruktif.

Adapun indikator-indikator penyelesaian konflik yang bersifat konstruktif adalah sebagai berikut: Bersikap lembut terhadap pasangan ketika menghadapi konflik meliputi, cara mengungkapkan ketidaksetujuan, atau perbedaan dengan bahasa yang mudah dimengerti oleh pasangan dan tidak membuat pasangan tersinggung atau merasa diusik. Membuat dan menerima upaya-upaya memperbaiki hubungan, dilakukan dengan cara menunjukkan kesediaan untuk mendengarkan pendapat pasangan, bersikap mengalah terhadap pasangan, atau membahas konflik yang disertai candaan (humor).Menenangkan diri sendiri dan pasangan, dilakukan dengan membujuk pasangan ketika ketegangan akibat konflik dirasakan meningkat, mengungkapkan rasa sayang sambil memeluk pasangan. Berkompromi, dilakukan dengan mengakui kesalahan yang telah dilakukan, mengubah sikap yang tidak berkenan bagi pasangan, dan memperbaiki kesalahan agar hubungan menjadi lebih baik. Saling bertoleransi, meliputi sikap bersedia mendengarkan keluhan pasangan, memaafkan, dan menerima pandangan yang berbeda.

Sedangkan perilaku penyelesaian konflik yang bersifat destruktif mengacu pada teori yang dikemukakan oleh Gottman mengenai prediksi perceraian yang didalamnya terdapat sejumlah perilaku yang dapat merusak hubungan individu dengan pasangannya. Perilaku destruktif dalam menyelesaikan konflik, mengacu dua dasar, yaitu ; 1) pada teori yang dikemukakan oleh Gottman (1994) mengenai perilaku yang mengarah pada perceraian atau ketidakstabilan perkawinan, dan 2) kajian hasil penelitian pendahuluan yang dilakukan oleh peneliti terhadap perempuan bercerai mengenai penyelesaian konflik yang ditampilkan. Peneliti melihat bahwa perilaku penyelesaian konflik perkawinan pada perempuan bercerai cenderung bersifat destruktif. Berdasarkan kajian teoritis dan hasil penelitian pendahuluan tersebut, peneliti menurunkan 5 indikator perilaku destruktif terhadap hubungan dengan pasangan yang dianggap sesuai untuk mengukur perilaku destruktif.

Perilaku destruktif tersebut meliputi: Menyerang pasangan dengan keras, individu menampilkan perilaku menyalahkan pasangan dengan nada marah, mengungkapkan kekurangan dengan kata-kata tajam, dan membantah dengan suara keras kepada pasangan. Saling menyakiti perasaan, meliputi saling menghina, bersikap keras kepala, tidak mau mendengar masukan atau pendapat pasangan. Menyerang terus menerus, meliputi menyalahkan pasangan secara terus menerus, dan mengkritik pasangan secara terus menerus. Tidak dapat berkompromi, meliputi saling mempertahankan pendapat masing-masing tanpa mau menerima masukan dari pasangan, menghindar untuk membahas konflik, dan merasa hubungan semakin buruk setelah berkonflik. Tidak dapat mengenang kebaikan pasangan, yaitu tidak dapat mengenang sesuatu yang menyenangkan tentang pasangan. 
Berdasarkan kajian teoritis tersebut, pengelompokkan pola-pola penyelesaian konflik menjadi dua pola yaitu, penyelesaian konflik perkawinan yang bersifat konstruktif dan penyelesaian konflik perkawinan yang bersifat destruktif akan diukur melalui indikator-indikator yang menggambarkan kedua pola penyelesaian konflik tersebut.

Selanjutnya penyelesaian konflik perkawinan ini akan dibahas berdasarkan usia perkawinan pasangan menikah. Untuk itu berikutnya akan dibahas mengenai tahapan-tahapan perkawinan. Dominian dalam James \& Wilson (2002) menguraikan fase-fase dalam perkawinan sebagai berikut:

Fase pertama, tahun pertama, fase ini merupakan masa sekitar tahun pertama perkawinan, hingga pasangan tersebut berusia akhir dua puluhan atau awal tiga puluhan, dengan demikian latar belakang dan permulaan hubungan juga penting sebagai suatu kejadian dalam perkawinan. Ineichen dalam James \& Wilson (2002) menyatakan bahwa masa tahun pertama, periode kenal-mengenal lebih singkat dan seringkali diasosiasikan sebagai perkawinan remaja. Thornes dan Collard dalam James \& Wilson (2002) menemukan bahwa masa ini merupakan periode awal perkawinan yang nampaknya secara kritis berhubungan dengan perkawinan yang stabil, ketika individu menghadapi permasalahan serius dalam perkawinan, maka pasangan suami istri seringkali tidak cepat memutuskan untuk berpisah, dan perkawinan yang sulit pada awal perkawinan cenderung dapat ditoleransi ketimbang periode yang lebih panjang, dimana sangat sedikit waktu untuk mengusahakan penyelesaian konflik.

Tugas sosial yang dijumpai pada fase awal ini menurut Dominian dalam James \& Wilson (2002) terdapat proses perpisahan dari orangtua dan teman dan lebih fokus pada perkembangan batin. Hal ini meliputi sejumlah kombinasi yang sebelumnya memisahkan aktivitas luang, semua hal ini akan menjadi lebih luas, kelangsungan adaptasi dimulai selaman masa saling kenal-mengenal dalam mempelajari peran baru, menciptakan jaringan baru, merevisi sesuatu yang sudah lama. Tugas sosial juga meliputi membangun hubungan interpersonal, mengatur rumah, mendukung secara finansial, saling berbagi tugas dan dalam banyak hal mengkombinasikan dua pekerjaan. Secara jelas, pada level ini, tugas tersebut sangat banyak dan kompleks, dan potensi masalah pun sangat besar.

Dominian dalam James \& Wilson juga menekankan pada kondisi fisik dalam perkawinan pada tahun pertama perkawinan yang berhubungan dengan penyesuaian seksual. Thornes dan Collard dalam James \& Wilson (2002) menemukan 10 hingga 20 persen pasangan mengalami ketidakpuasan seksual. Permasalahan yang dialami suami pada masa ini seputar ketidaksempurnaan, ejakulasi dini, dan impotensi. Sedangkan istri mengalami kegagalan untuk menikmati hubungan seksual, sehingga menimbulkan ketidakmampuan untuk bersikap rileks karena ketegangan yang dialaminya, atau ketakutan akan kehamilan, kemungkinan pula adanya kesulitan untuk menggabungkan antara hubungan asmara dan hubungan fisik (James \& Wilson, 2002). Tugas yang bersifat emosional dan kemampuan untuk beradaptasi terhadap kedekatan fisik dan kedekatan emosional juga merupakan hal utama pada masa ini.

Menurut Dominian dalam James \& Wilson (2002), pada setiap tahap perkawinan dibutuhkan kepekaan, respon yang akurat terhadap pasangan, empati, kemampuan mengekspresikan perasaan dan merasakan bahwa permasalahan yang dihadapi pasangan menjadi masalah bersama. Oleh karena itu terdapat dua permasalahan yang seringkali terjadi pada setiap tahap perkawinan yaitu kegagalam berkomunikasi secara tepat dan kesempatan untuk meluangkan waktu bersama yang kurang memadai. Kedua permasalahan ini menjadi sangat penting pada tahun pertama, karena menurut Diminian dalam James \& Wilson (2002) bahwa masa ini merupakan masa transisi dari jatuh cinta menjadi mencintai. Hal yang mempengaruhi seberapa mudah individu menjadi satu kesatuan dengan pasangannya adalah adanya latar belakang yang sama dalam pendidikan dan kecerdasan, meski hal ini bukan merupakan satu jaminan terjadinya komunikasi emosional, demikian pula dengan pentingnya dalam sebuah hubungan untuk berbagi standar dan nilai finansial, padangan politik, dan banyak lagi hal penting dalam perkawinan yang perlu dikerjakan untuk mengembangkan hal tersebut.

Fase kedua atau fase usia pertengahan, pada fase ini pasangan berusia antara 30 hingga 50 tahun dan telah melalui perkawinan selama beberapa tahun dan telah mengalami banyak perubahan. Pada fase ini suami istri lebih banyak menyibukkan diri dengan aktivitas membesarkan anak-anak hingga mereka besar dan meninggalkan rumah. Sebuah penelitian menghubungkan menurunnya kepuasan perkawinan berkenaan dengan periode membesarkan anak-anak, dan secara nyata menimbulkan tuntutan dan permasalahan berbeda tergantung jumlah dan usia anak (Dominian dalam James \& Wilson, 2002). Menurut Dominian, pada periode ini individu terus bertumbuh sebagai hasil dari perubahan dalam kepribadiannya.

Banyak permasalahan yang dijumpai pasangan pada periode ini berkembang atau menjadi lanjutan dari permasalahan pada tahun pertama kehidupan perkawinan mereka. masalah khusus dalam perkawinan pada fase usia pertengahan, meliputi pekerjaan dengan sejumlah faktor, tekanan mobilitas sosial, turun naiknya mobilitas, atau tidak adanya gerakan (mobilitas). Banyak suami yang telah mencapai batasan dalam karirnya atau pekerjaan potensial dan akan beradaptasi dengan pekerjaan dan berkurangnya kemampuan fisik, di samping itu para istri akan berhenti dari perkerjaannya (James \& Wilson, 2002). Permasalahan lain yang timbul pada fase ini adalah menghadapi anak-anak yang telah tumbuh sebagai remaja, yang merupakan tantangan tersendiri bagi orangtua. Selain itu kondisi fisik pada fase ini merupakan hal penting, dimana kebanyakan perkawinan pada fase ini mencapai kepuasan seksual dari perkawinannya, meski permasalahan seksual juga terus terjadi. 
Pada masa usia pertengahan setelah melewati tahun pertama perkawinan, hubungan mereka menjadi lebih matang oleh waktu. Tumbuh menjadi lebih mandiri, dan pasangan memindahkan ketergantungannya kepada orangtua kepada pasanganya, selanjutnya tumbuh menjadi percaya diri dan menyatu menjadi individu seutuhnya (James \& Wilson, 2002). Pertumbuhan dari ketergantungan menjadi mandiri merupakan kontribusi utama terjadinya perceraian. Terutama apabila bertepatan dengan sejumlah permasalahan lain yang dihadapi.

Fase ketiga, tahun-tahun akhir, fase ini merupakan akhir perkawinan yaitu dari usia lima puluh tahun dan berakhir dengan kematian pasangan. Kebanyakan perkawinan pada fase ini telah ditinggalkan oleh anakanak mereka, meninggalkan satu demi satu hubungan yang terkait dengan perkawinan. Dengan meningkatnya harapan hidup, pada fase ini perkawinan kemungkinan berlangsung dua puluh tahun terakhir atau lebih lama, dengan managemen usia menambah isu-isu penting. Pada fase ini mereka merasakan kebebasan untuk berbagi atau keterbatasan aktivitas karena kondisi fisik yang menurun.

Subjek dalam penelitian ini berada pada fase pertama dan fase kedua yaitu fase tahun pertama dan fase usia pertengahan, dimana subjek penelitian kemungkinan telah memasuki usia perkawinan di atas 2 tahun. Peneliti pun menetapkan usia individu menikah dalam penelitian ini berada pada usai dewasa. Dengan demikian subjek dalam penelitian ini dapat digolongkan berada pada fase pertama dan fase kedua dalam perkawinan menurut Dominian.

Berdasarkan uraian di atas peneliti melihat bahwa penyelesaian konflik perkawinan memiliki hubungan yang sangat erat dengan usai perkawinan individu, karena setiap tahapan dalam perkawinan memiliki perebedaan-perbedaan yang dirasakan individu baik secara fisik maupun psikologis. Oleh karena itu munculah pertanyaan apakah penyelesaian konflik perkawinan dapat dibedakan berdasarkan usia perkawinannya. Untuk mengetahui bagaimana penyelesaian konflik perkawinan ditinjau dari usia perkawinan pada pasangan menikah, maka dilakukan penelitian mengenai penyelesaian konflik perkawinan dapat dibedakan berdasarkan usia perkawinan pada pasangan menikah.

\section{METODE}

Penelitian ini bertujuan untuk mengetahui bagaimana gambaran perbedaan bentuk penyelesaian konflik ditinjau dari usia perkawinan pada pasangan menikah. Metode yang digunakan untuk menjelaskan penelitian ini adalah metode descriptive. Responden dalam penelitian ini terdiri dari 378 laki-laki dan 455 perempuan yang tersebar di Kota Makassar dengan kriteria telah menikah. Pemilihan subjek penelitian dilakukan dengan non random sampling yaitu metode yang memiliki syarat bahwa tidak semua anggota populasi memiliki peluang yang sama untuk menjadi sampel. Teknik pengambilan sampel menggunakan teknik accidental sampling, yaitu teknik yang digunakan untuk mencari informasi yang diperlukan kepada siapapun yang ditemui (Paturochman, 2012). Dari 833 orang responden yang diteliti, 4 orang $(0,5 \%)$ berada pada berusia di bawah 20 tahun, 585 orang $(70,2 \%)$ berusia 20-40 tahun berada pada usia dewasa awal, dan 244 orang $(29,3 \%)$ berusia $41-60$ tahun berada pada usia dewasa pertengahan. Berdasarkan usia perkawinan, dari 833 orang responden yang diteliti, 416 orang $(49,9 \%)$ diantaranya memiliki usia perkawinan di bawah 10 tahun, 266 orang (31,9\%) diantaranya memiliki usia perkawinan 10-20 tahun, 119 orang $(14,3 \%)$ diantaranya memiliki usia perkawinan 21-30 tahun, dan 32 orang (3,8\%) diantaranya memiliki usia perkawinan $>30$ tahun. Hal ini mengindikasikan bahwa sebagian besar responden, berada pada usia perkawinan $<10$ tahun.

Penelitian ini menggunakan kuesioner untuk mengukur penyelesaian konflik perkawinan pada pasangan menikah dengan menggunakan skala penyelesaian konflik perkawinan. Skala ini telah melalui uji validitas dan reliabilitas alat ukur, dimana reliabilitas alat ukur adalah koefisien Cronbach's alpha dilakukan dengan menggunakan bantuan program SPSS for windows 22. Hasil analisis reliabilitas penyelesaian konflik konstruktif 0.933 dan reliabilitas alat ukur penyelesaian konflik destruktif 0.944. Sedangkan hasil uji validitas menyatakan bahwa 11 item penyelesaian konflik konstruktif valid, dan 15 item penyelesaian konflik destruktif yang dinyatakan valid. Untuk menghubungkan penyelesaian konflik perkawinan dengan usia perkawinan dilakukan cross tabulation menggunakan bantuan program SPSS for windows 22 .

\section{HASIL DAN PEMBAHASAN}

Gambaran mengenai bagaimana perbedaan bentuk penyelesaian konflik perkawinan ditinjau dari usai perkawinan pada pasangan menikah. Setelah dilakukan perhitungan diketahui bahwa penyelesaian konflik perkawinan yang terdiri dari pola penyelesaian konflik perkawinan konstruktif dan penyelesaian konflik perkawinan destruktif merupakan pola yang keduaduanya digunakan ketika menghadapi konflik, akan tetapi masing-masing pola tersebut menunjukkan kadar yang berbeda-beda sesuai usia perkawinan. Selain itu kadar tinggi-rendahnya intensitas penyelesaian konflik pada kedua pola tersebut dipaparkan berdasarkan kategori. Kategori tinggi artinya pasangan menikah menampilkan penyelesaian konflik konstruktif yang lebih menonjolkan sikap lemah lembut, bertoleransi terhadap kekurangan pasangan, berupaya memperbaiki hubungan, menenangkan diri sendiri dan orang lain, serta berkompromi terhadap kesalahan pasangannya.

Pasangan menikah dengan usia perkawinan kurang dari 10 tahun menunjukkan penyelesaian konflik konstruktif ketika berkonflik dengan pasangannya yaitu $17,8 \%$ berada pada kategori rendah, sedangkan pasangan menikah dengan usia perkawinan kurang dari 10 tahun menunjukkan penyelesaian konflik konstruktif dengan kategori tinggi yang dilakukan pasangan menikah yaitu $32 \%$ berada kategori tinggi (lihat table 3.1.) Kondisi ini menggambarkan bahwa pasangan menikah yang memiliki usia perkawinan kurang dari 10 tahun pada umumnya cukupberupaya melakukan polapola konstruktif dalam menyelesaikan konflik. 
Pasangan menikah dengan usia perkawinan antara 10-20 tahun lebih sering menampilkan penyelesaian konflik konstruktif dengan kategori tinggi yaitu 18,7\% dibandingkan penyelesaian konflik konstruktif dengan kategori rendah yang berada pada $13,2 \%$. Di samping itu pasangan yang berada pada usia perkawinan 21 hingga 30 tahun, pada umumnya menampilkan penyelesaian konflik yang konstruktif dengan kategori tinggi yaitu 7,9\%. Akan tetapi berbeda dengan pasangan menikah dengan usia perkawinan di atas 30 tahun, dimana pada usia ini pasangan menikah cenderung lebih rendah dalam menampilkan penyelesaian konflik konstruktif yaitu 2,1\%. Sedangkan pasangan menikah dengan penyelesaian konflik konstruktif yang berada pada kategori rendah sekitar $1,7 \%$.

Dengan demikian ditinjau dari tahapan usia perkawinan diketahui bahwa pada umumnya pasangan menikah berada pada usia perkawinan di bawah 10 tahun, menampilkan penyelesaian konflik yang konstruktif dengan kategori tinggi. Artinya pasangan menikah pada usia perkawinan di bawah 10 tahun mampu bersikap lemah lembut, bertoleransi terhadap kekurangan pasangan, berupaya memperbaiki hubungan, menenangkan diri sendiri dan orang lain, serta berkompromi terhadap kesalahan pasangannya.

Bila dikaji berdasarkan tahapan usia perkawinan, Thornes dan Collard dalam James \& Wilson (2002) menemukan bahwa masa ini merupakan periode awal perkawinan yang nampaknya secara kritis berhubungan dengan perkawinan yang stabil, ketika individu menghadapi permasalahan serius dalam perkawinan, maka pasangan suami istri seringkali tidak cepat memutuskan untuk berpisah, dan perkawinan yang sulit pada awal perkawinan cenderung dapat ditoleransi ketimbang periode yang lebih panjang, dimana sangat sedikit waktu untuk mengusahakan penyelesaian konflik. Mengacu pada pendapat tersebut, maka dapat dikatakan bahwa penyelesaian konflik yang konstruktif pada masa perkawinan di bawah 10 tahun meski cukup kritis, namun pada umumnya dapat dilakukan karena adanya tolenransi yang lebih tinggi, dibandingkan pada usia perkawinan yang lebih lama.

Pasangan menikah dengan usia perkawinan kurang dari 10 tahun jumlahnya lebih banyak menampilkan penyelesaian konflik destruktif dengan kategori tinggi yang lebih dominan. Pasangan menikah dengan usia perkawinan antara 10-20 tahun 26\% menampilkan penyelesaian konflik destruktif dengan kategori tinggi. Kondisi ini nampaknya sejalan dengan pasangan yang berada pada usia perkawinan 21 hingga 30 tahun, pada umumnya menampilkan penyelesaian konflik yang destruktif dengan kategori tinggi yaitu 11,4\%, akan tetapi pasangan menikah pada usia perkawinan ini hanya berjumlah 95 orang dari total responden yang berjumlah 833 .

Sedangkan pasangan menikah dengan usia perkawinan di atas 30 tahun, jumlahnya sangat sedikit, sehingga dari segi presentasi pun tergolong sedikit, namun demikian pasangan menikah yang menampilkan penyelesaian konflik destruktif kategori tinggi juga lebih banyak.

\section{SIMPULAN}

Berdasarkan uraian hasil di atas diketahui bahwa penyelesaian konflik konstruktif lebih dominan ditampilkan pada pasangan menikah dengan usia perkawinan di bawah 10 tahun. Demikian pula dengan pasangan menikah usia perkawinan antara 10 hingga 20 tahun yang menampilkan penyelesaian konflik konstruktif yang lebih kuat. Ketika berkonflik dengan pasangannya, mereka lebih menonjolkan sikap lemah lembut, bertoleransi terhadap kekurangan pasangan, berupaya memperbaiki hubungan, menenangkan diri sendiri dan orang lain, serta berkompromi terhadap kesalahan pasangannya. Demikian pula dengan penyelesaian konflik destruktif, juga terlihat dominan pada kategori tinggi. Hal ini menunjukkan bahwa pasangan menikah kemungkinan dapat menampilkan penyelesaian konflik yang berbeda-beda sesuai dengan masalah yang dihadapinya. Dalam penelitian ini tidak ditemukan hal yang membedakan mengapa pasangan menikah menampilkan penyelesaian konflik yang konstruktif, ataupun mengapa pasangan menikah menampilkan penyelesaian konflik yang destruktif. Akan tetapi penelitian ini dapat menjelaskan penyelesaian konflik berdasarkan usia perkawinannya.

\section{DAFTAR PUSTAKA}

Bermundez, Maria Judith. 2002. Conflict Resolution Among Latino Couple. Dissertation.Virginia. Virginia Polytechnic Institute and State University.

Deutsch, Morton. Coleman,Peter T. \& Marcus, Eric. 2006. The Handbook of Conflict Resolution; Theory and Practice. San Francisco. Jossey-Bass A Wiley Imprint.

Fincham, Frank D., Beach, Steven R.H., \& Davila, Joanne. 2004. Forgiveness and Conflict Resolution in Marriage. Journal of Family Psychology. New York. The American Psychology Association. Inc.

Fitzpatrick, M.A. 1988. Negotiation, Problem Solving and Conflict in Various Types of Marriage dalam perspectives on Marital Interaction. Philadelphia. Multiligual Matters Ltd.

Gottman. John M. 1994. The Seven Principle for Making Marriage Work. New York. Crown Publishers, Inc.

Gottman, John M. \& Levenson, Robert W. 1988. The Social Psychophysiology of Marriage I dalam Noller \& Fitzpatrick (Editor). Perspective on Marital Interaction. Philadelphia. Multiligual Matters Ltd.

Gottman, John M. \& Levenson, Robert W. 2002. A Two-Factor Model for Predicting When a Couple Will Divorce: Exploratory Analyses Using 14 Year Longitudinal Data. Family Process. Vol. 41 FPI, Inc.

James, Adrian L, \& Wilson, Kate. 2002. Couple, Conflict, and Change: social work. London. The Taylor \& France e-Library.

Jones. Beach. \& Fincham. 2006. Family Relationship and Depression dalam The Cambridge Handbook of Personal Relationship (edited by Vangelisti \& Perlman). Cambridge. Cambridge University Press.

Miller, Rowland S. \& Perlman, Daniel. 2009. Intimate relationship.Fifth Edition. New York. McGraw Hill.

Muin, St. Murdiana (2014) Penyelesaian Konflik Perkawinan pada Perempuan Bercerai dan Perempuan Menikah di Kota Makassar (Proceeding, ).Surabaya. Temu Ilmiah Nasional

Neff, A. Lisa \& Karney, R Benyamin. 2002. Self Evaluation Motives in Couple Relationship: A Model of Global Enhancement and Spesific Verifikation dalam Noller dan Feeney (Editor). Understanding Marriage. New York. Canbridge University Press.

Paturochman, 2012. Penentuan Jumlah dan Teknik Pengambilan Sampel. Bandung. Unpad Press.

Reber \& Reber .2010. Kamus Psikologi. (terjemahan). Yogyakarta. Pustaka Pelajar.

Lim, Ben K H. 2000. Conflict Resolution Styles, Somatization, and Marital Satisfaction in Chinese Couple: Moderating Effect of Forgiveness and Willingness to Seek Profesional Help. Disertation. Texas. Texas tech University. 


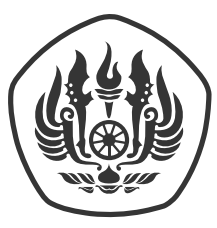

\section{IJAS}

Indonesian Journal of Applied Sciences

Jurnal IImiah Program Pascasarjana Universitas Padjadjaran

\section{PETUNJUK PENULISAN}

\section{Pendaftaran artikel dan Proses Review}

Manuskrip tulisan dapat di kirim dalam bentuk hard copy yang disertai soft copynya melalui pos ke alamat redaksi atau dikirim secara elektronik berupa file melalui e-mail: publikasi@pasca.unpad.ac.id atau publikasi.pps@gmail.com Soft copy dikirim dalam bentuk MS Word file dan PDF file yang tidak melebihi 10 MB, yang meliputi teks tulisan, table dan gambar. Tiap baris dari tulisan sebaiknya diberi nomor pada sisi sebelah kiri (gunakan penomoran otomatis dalam MS Word). Tulis alamat email dari penulis untuk keperluan komunikasi.

\section{Hak Cipta (Copyright)}

Hak cipta dari tulisan akan menjadi hak penuh Indonesian Journal of Applied Sciences setelah tulisan di publikasi.

\section{Petunjuk Penulisan untuk Naskah Lengkap (Regular papers)}

Penulis harus selalu merujuk ke cara penulisan dalam terbitan terakhir IJAS. Penulis yang akan menulis dalam bahasa Inggris, diharuskan untuk mengecekkan tulisannya ke ahli bahasa Inggris terlebih dahulu sebelum mengirimkannya ke dewan redaksi IJAS. Manuskrip ditulis dalam 1.5 spasi dengan menggunakan huruf Times New Roman 12 pts dengan menggunakan jarak margin untuk semua sisi sebesar $2.5 \mathrm{~cm}$. Gunakan kertas putih ukuran A4. Semua halaman diberi nomor secara berurutan termasuk daftar pustaka.

\section{Susunan Manuskrip:}

Tulisan disusun dalam urutan sebagai berikut:

- Judul Berjalan (running title)

- Judul (bahasa Indonesia dan bahasa Inggris)

- Nama Penulis

- Institusi, alamat, kode pos dan negara

- Catatan kaki (berisi kapan tulisan diterima dan disetujui untuk diterbitkan, alamat email penulis untuk korespodensi dan singkatan yang dipakai dalam tulisan jika ada)

- Abstrak (bahasa Indonesia dan bahasa Inggris)

- Kata kunci (bahasa Indonesia dan bahasa Inggris)

- Pendahuluan

- Bahan dan Metode

- Hasil dan Pembahasan

- Ucapan Terimakasih

- Daftar Pusataka

Judul Berjalan: adalah judul singkat dan nama penulis pertama yang terletak sebagai header di setiap halaman tulisan. Judul berjalan harus cukup pendek tidak lebih dari 100 huruf termasuk nama penulis.

Judul Makalah: Judul dalam Bahasa Indonesia dan Bahasa Inggris ditulis dengan huruf Times New Roman ukuran 14 spasi tunggal (judul tidak melebihi 20 kata) dan dicetak tebal. Setiap huruf awal dari kata dalam judul ditulis dengan huruf besar kecuali untuk kata sambung dan preposisi. Apabila ada subtitle ditulis dengan huruf biasa (plain) ukuran 12 pts.

Nama penulis ditulis dengan huruf Times New Roman 12pts dan dicetak tebal. Semua penulis diberi note untuk menunjukkan asal institusi. Institusi dan alamat ditulis dengan menggunakan Times New Roman 10pts dan dicetak miring.

Abstrak: Bagian ini harus menggambarkan secara lengkap esensi penelitian yang meliputi latar belakang dan tujuan penelitian secara singkat, hal penting dari metode dan materi yang digunakan dan ditulis secara singkat, hasil penelitian yang dianggap penting dan kesimpulan bila ada. Tidak boleh ada kutipan gambar, table atau daftar pustaka. Perincian perlakuan tidak perlu dicantumkan, kecuali jika memang merupakan tujuan utama riset.

Kata kunci: gunakan huruf Times New Roman 10pts, dicetak miring, huruf kecil semua, dituliskan secara alfabetis maksimum 5 kata. Kata kunci mengacu kepada judul artikel. 
Heading: Headings adalah judul untuk tiap bagian di dalam suatu tulisan jurnal seperti: Bahan dan Metode, Hasil dan Pembahasan dan sebagainya. Semua headings ditulis menggunakan huruf Times New Roman 12pts dan dicetak tebal dengan posisi di sebelah kiri. Apabila ada sub judul dari headings maka diberi nomor dan disusun dengan urutan sebagai berikut: $1,2,3 ;(1),(2),(3) ; 1), 2), 3) ; a, b, c$

Catatan kaki: catatan kaki terletak pada halaman pertama. Tanggal penerimaan dan persetujuan penerbitan akan diberikan oleh Tim Editor. Alamat korespodensi penulis (e-mail atau fax) ditulis di catatan kaki. Jika alamat penulis telah berubah, alamat baru dapat ditulis di catatan kaki. Jika diperlukan penyandang dana penelitian dapat ditulis di catatan kaki. Singkatan yang dipakai dalam teks sebaiknya ditulis di catatan kaki secara alphabet. Hindari penggunaan catatan kaki yang berlebihan. Contoh catatan kaki dapat dilihat di bawah ini:

Diterima 1 Januari 2010. Disetujui 1 April 2010. Alamat Korespondensi: T.Haru (haru@unpad.ac.id; fax+227796320, alamat sekarang: Program Pascasarjana Universitas Padjadjaran, Jl. Dipati Ukur 35, Bandung ). Penelitian ini sebagian telah didanai dari Hibah Bersaing Dikti.

Singkatan: ANOVA: analysis of variance; NR: nitrate reductase; TNC: total non structural carbohydrate.

Teks tulisan: Semua teks tulisan ditulis menggunakan huruf Times New Roman 12pts dengan 1.5 spasi. Awal paragraf dibuat menjorok (indented). Penulisan singkatan untuk pertama kali muncul dalam teks, harus diikuti dengan kepanjangannya. Untuk selanjutnya cukup ditulis singkatannya. Cara penulisan nama latin mengikuti International Code of Botanical Nomenclature dan ditulis dengan huruf miring sebagai contoh Setaria italic Beauv. var. gemanicum Trin. Nama kimia lebih baik disajikan dalam bentuk nama daripada symbol, kecuali nama kimia dengan struktur kimia yang sangat kompleks. Gunakan satuan menurut sistem metriks dan standar internasional. Bilangan dari nol sampai sembilan, ditulis dalam kata, kecuali jika angka tersebut diikuti satuan. Contoh: $7 \mathrm{ml}$ h-1, g g-1, g L-1, dan mL L-1. Jangan menggunakan garis miring untuk menulis kombinasi dari satuan. Pengutipan tabel dan gambar menggunakan "Tabel \#" dan "Gambar \#" untuk mengutip tabel atau gambar dalam teks. Di dalam narasi, gunakan huruf awal kapital jika kata 'tabel" dan "gambar" diikuti angka, contoh: Tabel 3, Gambar 4.

Pendahuluan: Bagian pendahuluan berisi permasalahan/ konsep/ hasil penelitian sebelumnya yang merupakan dasar dilakukannya penelitian ini. Pendahuluan juga harus menjelaskan latar belakang dan mengapa topik penelitian dianggap penting untuk dilakukan. Bagian ini diakhiri dengan tujuan penelitian. Hindari penulisan pendahuluan yang terlalu panjang dan gunakan hanya kutipan-kutipan pustaka terbaru untuk mendukung mengapa penelitian ini dilakukan. Pada bagian akhir pendahuluan tuliskan tujuan secara jelas dari penelitian ini.

Bahan dan Metode: Bagian metode harus menjelaskan tentang tahap penelitian secara rinci dan jelas, termasuk spesifikasi bahan dan alat serta metode penelitiannya, sehingga dapat dirujuk oleh peneliti lain (repeatable and reproduceable). Jika metode yang digunakan telah diketahui sebelumnya, maka pustakanya harus dicantumkan. Untuk penelitian yang komplek dan berseri dapat dibuat sub judul - sub judul untuk menjelaskan kompleksitas metode maupun tahapan penelitian yang dilakukan.

Hasil dan Pembahasan: Hasil dan pembahasan dapat ditulis terpisah atau digabung dalam satu kesatuan. Untuk tulisan yang harus menyajikan banyak data dengan tahapan - tahapan percobaan, sebaiknya pembahasan di pisah dari hasil. Secara umum hasil dan pembahasan menyajikan hal sebagai berikut:

a. Hasil: Hasil penelitian dalam bentuk data merupakan bagian yang disajikan untuk menginformasikan temuan penelitian tersebut. Ilustrasi hasil penelitian dapat berupa grafik/ tabel/ gambar yang diberi keterangan secukupnya agar mudah dimengerti. Hindari pembacaan kembali data - data hasil penelitian yang telah tersaji dalam bentuk Tabel ke dalam bentuk kalimat, kecuali ada hal sangat penting yang perlu diungkapkan di dalam pembahasannya. Keterangan tabel dan grafik harus lengkap. Jika ada persamaan matematika harus dituliskan dengan indent $1.27 \mathrm{pts}$, dan diberi nomor berurutan dimulai dari (1) yang diatur rata kanan. Sebagai contoh:

$$
x^{2}+y^{2}=z^{2}
$$

Temuan yang di luar dugaan harus dibahas dengan rinci disertai teori pendukungnya.

b. Pembahasan: Di dalam pembahasan dikemukakan keterkaitan antara hasil penelitian dengan teori, tujuan penelitian, serta perbandingan dengan penelitian lain yang telah dipublikasikan. Pembahasan juga menjelaskan implikasi/ kontribusi temuan bagi ilmu pengetahuan.

Ucapan Terimakasih: Dibuat ringkas sebagai ungkapan terima kasih kepada pihak yang membantu riset, penelaah naskah, atau penyedia dana riset. 
Daftar Pustaka: Pustaka yang dikutip dalam teks harus persis sama dengan yang ada di Daftar Pustaka, dan sebaliknya. Daftar Pustaka ditulis dengan lengkap dan berurutan alfabetis, sehingga pembaca yang ingin menelusuri pustaka aslinya akan dapat melakukannya dengan mudah. Hanya pustaka yang telah diterbitkan yang boleh dicantumkan. Penulisan daftar pustaka menggunakan sistem penulisan nama penulis artikel yang berlaku internasional (nama belakang sebagai entry), terlepas apakah nama belakang penulis artikel merupakan nama marga atau bukan. Kutipan nama penulis di dalam teks, harus ditulis sebagai berikut:

- Untuk dua orang penulis, kutipan penulis di dalam teks harus ditulis lengkap seperti: Inaba and Yoshida (2004) atau (Inaba and Yoshida, 2004), dan untuk penulis lebih dari dua orang, kutipan penulis di dalam teks hanya ditulis penulis pertama saja seperti: Yoshida et al. (2009) atau (Yoshida et al., 2009).

- Baris kedua dari suatu pustaka ditulis menjorok ke dalam setelah lima spasi/ ketukan.

- Jumlah pustaka dibatasi hingga 25 buah dan sebaiknya merujuk pada tulisan yang terbit dalam satu dekade terakhir. Contoh penulisan pustaka:

» Penulisan Pustaka berupa Buku: Semua huruf awal dari suatu Judul buku ditulis dengan huruf kapital. Khetan, S.K. 2001. Microbial Pest Control. Marcel Dekker, Inc. New York-Basel. 300 pp.

» Penulisan Pustaka Jurnal

Ushiyama, T., Nakamura, K., Anas and Yoshida, T. 2009. Pedigree analysis of early maturing wheat cultivars in Japan for breeding cultivars with higher performance. Plant Prod. Sci. 12(1): 80-87pp.

» Penulisan Pustaka yang Diakses dari Internet dan CD Rom

Black, A.S. and White, T.A. 2005. New Crop management method for high and sustainable agriculture. [Online]. Available at www.jps.econ/research/pro.org/cm/. Crop Production Research. doi: 10.1094/cm-2002-090501-RS. J. Agro-physical Science.

Rice, J.S., Wheat, S.D. and Jackson, H.G. 2007. A spectral analysis for integrated crop management. In S.D. Wheat and H.G. Jackson eds., Proc. 10th World Conference on Precision Farming [CD-ROM]. World Society of Agronomy.

\section{Petunjuk Penulisan untuk Tulisan Laporan Singkat (short paper)}

Artikel Laporan Singkat adalah tulisan hasil penelitian atau bagian dari penelitian yang harus segera diinformasikan. Panjang artikel maksimum empat halaman naskah.

Naskah tulisan Laporan Singkat secara umum mengikuti sistematika penulisan seperti naskah lengkap, namun bereda dalam penulisan dalam daftar pustaka. Sistematika penulisan terdiri dari: Judul dan Nama Penulis lengkap dengan alamat pos (ditulis sentris), diikuti oleh Abstract (dengan keywords); Abstrak (dengan kata kunci); Isi artikel yang secara implisit berisi pendahuluan, bahan dan metode, hasil dan pembahasan serta kesimpulan; ucapan terimakasih; daftar pustaka.

Contoh penulisan daftar pustaka untuk Laporan singkat:

Anas et al. 2000. Plant Prod. Sci. 3 : 246-253.

Bernzonsky, W.A. 1992. Genome 35 : 689-693. 